\title{
The orange and the 'Cross in the Crescent': imagining Palestine in 1929
}

\author{
TAMIR SOREK \\ Department of Sociology, Cornell University, Ithaca, NY 14853, USA
}

\begin{abstract}
This article analyses a public discussion held in Palestine during the last months of 1929 over proposals for a particular Palestinian flag. Based on readers' reactions published in the daily newspaper Filastin and on letters sent to the Arab Executive, the article examines the character of Palestinian identity as it was imagined by a certain segment of the Palestinian elite. The three main leitmotifs of the flag proposals - the four colors of the Arab flag, the color orange and the 'Cross in the Crescent' emblem - serve as a starting point for discussing the tensions between Palestinian particularism and pan-Arabism, as well as the status of Muslim-Christian partnership in a period of increasing Islamisation of Palestinian identity. The second part of the article incorporates a comparative discussion that aims to explain the failure of the color orange and the 'Cross in the Crescent' to be accepted as emblems in the national flag. By comparing the unsuccessful proposals with the Arab flag (that eventually became the official Palestinian flag) and with the Lebanese flag, the article suggests their failure was due to three main reasons: (a) they reflected the interests of relatively marginal social groups; (b) they were not raised at a time of sweeping change in the socio-political order; and (c) they lacked a profound basis in local tradition and the potential to be attached to an ancient past.
\end{abstract}

\section{Introduction}

The year 1929 was a significant milestone in the development of Palestinian national identity. In August, a series of violent riots known in Palestinian collective memory as 'thawrat al-burak' erupted all over Palestine. The British forces were helpless in their attempts to defend Jewish neighborhoods and settlements, and their harsh measures to end the riots cost the lives of many Palestinians. In the bloodiest confrontations since the beginning of Zionist immigration at the end of the nineteenth century, 133 Jews and 116 Arabs lost their lives in one week. The aftermath of the riots, and mainly the British decision to appoint a commission of inquiry to investigate events, created the impression that the destiny of Palestine was at stake and would be determined in the very near future.

In this atmosphere of tension and national awakening, in October 1929 an Arab citizen from Haifa named Kamel Yusuf Ghamashi sent a letter to the 
Arab Executive ${ }^{2}$ and asked its members to create a particular flag and anthem for Palestine: 'The Mandatory Government knows how to make the Arabs forget their most sacred national duties and how to dismantle their ranks and undermine their unity - and we do not have a flag to unify us like the Zionists'. ${ }^{3}$ While there is no evidence that the AE itself ever discussed Ghamashi's suggestion, his call fell on receptive ears among the editorial board of the important Arab newspaper Filastin, published in Jaffa. On 20 October 1929, Filastin published on its front page a proposal to establish a Palestinian flag and anthem:

We are an ancient nation with a glorious history and a culture that generously contributed its share to the world's culture and civilization. And here, Allah has chastised us by the hands of Europe and tortured us by dividing us. Then, things have stabilized so that Palestine became a country in itself and the rest of the Arab states have turned to fight - first, every state for itself and only later for Arab unity.

... only the British flag was hoisted above Palestine. The Zionists came and they have a flag that still flutters. ... In light of this, we are asking, is it possible that one hundred thousand Jews have a need for 'unity' but eight hundred thousand Arabs do not have the same thing? Is it possible that only two flags will flutter in the sky of Palestine, both of which are foreign and uninvited? Is it possible that our sons will ask us about their citizenship and we will tell them that they are Arab Palestinians and call them to love Arab Palestine but we will not give them an emblem towards which they will look and will see their country in it?

Following that, the author presented two proposals for a new Palestinian flag (Figure 1a) and a proposal for an anthem, and invited readers to send their reactions. Over the next several weeks readers from Jaffa, Haifa, Jerusalem, Acre, Nablus, Nazareth, Bethlehem and Gaza sent their reactions to the newspaper or directly to the AE. Filastin's proposals, its readers' reactions and their own proposals constitute a thrilling document that offers a glance into the collective self-image of a self-conscious elite trying to lead a national movement in its formative stage. The charged controversies over the desired relationship between Arab nationalism and Palestinian identity, the question of Palestinian distinctiveness, as well as the relations between Palestine's religious communities and emerging Palestinian nationalism - all received a colorful visual representation. ${ }^{4}$

Still, what is most interesting about these proposals is the fact that they were not accepted, not at all on the institutional level and only occasionally on the popular level. The new emblems that were proposed by the newspaper's editor and his readers vanished from the collective consciousness of Palestinians as national emblems.

This popular rejection, or at least indifference, to attempts to magnify Palestinian territorial distinctiveness on the symbolic level is puzzling. It calls for a comparative discussion that will juxtapose these proposals with two other flags that were officially and popularly accepted as national flags in temporal and spatial contiguity to Filastin's proposals. First I compare the 'Arab flag', namely the four-color flag of the 'Arab revolt' against the Ottomans, ${ }^{5}$ some of whose variants became the official flag of several Arab 
countries. This flag's use had spread relatively rapidly in Palestine only a decade earlier, even without central supportive institutions and in spite of inimical British rule. The second flag discussed is the Lebanese national flag that accentuates Lebanese distinctiveness by placing the Lebanese cedar at its center. These comparisons enable a discussion of the factors that limit or facilitate the ability of the elite to invent national symbols to be adopted by the masses.

Based on those comparisons, I argue that the new emblems offered by Filastin and its readers did not gain a place on the official Palestinian flag and disappeared from Palestinian collective memory because they did not fulfill even one of three important conditions: (a) hegemony of the groups whose interests the emblems reflected; (b) being raised at a time of sweeping change in the socio-political order, when the consciousness of the masses is more likely to adopt new symbols; and (c) a strong and profound basis in local tradition and the potential to be attached to an ancient past.

\section{The significance of national flags}

Key symbols are central to the construction of any sort of collective identity. Among functionalist and interactionist thinkers who deal with symbols there is a tendency to identify the classic symbols of nationalism, namely the flag and the anthem, as specific cases of symbols that serve as the collective representation of a society, in the Durkheimian meaning of the term. Since Bellah's classic essay 'Civil Religion in America' (1967), the flag and the anthem are mentioned frequently as 'totems' of the secular nation, which serve the exact same sociological function as the cross serves for Christianity or the Buddha statue serves for Buddhism. This analogy has gained a nearly axiomatic status among sociologists, despite the significant differences between nationalist symbols and other symbols.

Durkheim describes the totem as an object that a society defines as sacred. However, there are no additional concrete requirements concerning its origin, and the totem may be an animal, a vegetable or an inanimate thing (Durkheim 1969 [1915]: 124). By comparison, unlike religious symbols, national symbols are standard. Despite the differences between the flag of each specific state, every state needs the same set of symbols in order to realise its 'nation-ness'. A nation-state needs to have a capital city, unique stamps, a national day, a national anthem - and above all it needs a national flag that constitutes the focus of every national ceremony. The flag is so central to the idea of nationhood that it is impossible to imagine the existence of a nation without it. To 'be a nation' means to be a part of the 'family of nations' and this requires fulfilling certain symbolic standards. As Weitman (1973: 343) wisely indicated:

"Most nation states do not try to MAXIMIZE their distinctiveness from other nations through their flags. Had they wished to do so, they could have used a greater variety of 
flag proportions, colors, color combinations, geometrical patterns, field devices, etc... The nation state finds it of paramount importance to communicate that IT IS A NATION-STATE, i.e., that it belongs to the inter-national club, that it is 'one of them'." (capitalisation in original)

Therefore, the meaning of establishing a flag by a national movement is much more than a proclamation of identity. As a result of their standard qualities, the centrality of the flag in nationalist experience is essentially distinct, in comparison to symbols of religious community or voluntary organisation, for example. Religious communities and trade unions may but do not necessarily have to have flags, because there is no standard set of symbols that constitute the ideal type of religious community or trade union. A national community, however, must have a flag in order to comply with the standard set of symbols of the nation's ideal type.

Hence, the demand rising from Filastin's editorial to establish a particular Palestinian flag is actually a demand for a declaration of national independence in the symbolic realm. This is a significant stage in the process of the creation of Palestinian national identity. Although a distinct Palestinian identity can be traced back at least to the middle of the nineteenth century (Kimmerling and Migdal 1993; Khalidi 1997b), or even to the seventeenth century (Gerber 1998) it was not until after World War I that a broad range of optional political affiliations became relevant for the Arabs of Palestine. During the short rule of Faysal the Hashemite in Damascus from October 1918 until July 1920, the possibility of being a part of a Greater Syria seemed to be the most promising option for the Palestinian elite (Porath 1974; Khalidi 1997a, b). The evaporation of the Greater Syrian adventure with the French occupation of Damascus launched a process in which Arab Palestinians turned to articulate their political identity more and more in particularistic Palestinian terms. The riots of August 1929 and the harsh reactions of the British authorities strengthened this tendency and led to a surge of national awakening.

Obviously, this awakening received different meanings and expressions among various groups. The newspaper Filastin that published the flag proposals was supported mainly by the subscriptions of educated Christians. Although when the cousins 'Isa and Yusuf al-'Isa established the newspaper in 1911 their motivation was to defend the interests of the Arab Orthodox (Rumi) community, very soon they found themselves defending the national Palestinian cause (Khalidi 1997a). Although al-'Isa did not abandon the Orthodox cause, Filastin tended to maintain a supra-religious orientation in its writing, stressing frequently the unity of interests of Christians and Muslims in Palestine in the face of colonialism. The newspaper was also the most prominent and consistent opponent of the aspiration to see Palestine as part of a Pan-Arab state and instead was committed to the idea of a particular Palestinian identity (Kabha 1996).

These tendencies of Palestinian particularism and supra-religious spirit were reflected in the public debate that surrounded the flag proposals. This 
debate exposes three central themes around which Palestinian national identity was shaped among Filastin's readers: (a) continuum with an ancient glorious past - represented by the four colors of the 'Arab flag'; (b) geographic distinctiveness of Palestine and a natural connection between the Palestinian people and its land - represented by a local crop, the orange; (c) Palestinian identity as a bridge between Muslims and Christians represented by the 'Cross in the Crescent' emblem.

\section{Four Arab colors - the construction of a glorious past}

Filastin published two proposals for the Palestinian flag on 20 October 1929. The first included only the four colors of the Arab flag - white, black, green and red. They appear as four triangles that comprise a rectangle - each one of the triangles has a base that overlaps one of rectangles' ribs (Figure 1b). ${ }^{6}$ The second proposal included a fifth color, orange. Both proposals were inspired by the original 'Arab flag', which includes three horizontal stripes in green, black and white, with a red triangle on the side.

Modern national movements frequently cling to a 'golden age of communal splendour, with its sages, saints and heroes, the area in which the community achieved its classical form, and which bequeathed a legacy of glorious memories and cultural achievements' (Smith 1986: 191). In modern Arab nationalism, the Arab flag as a 'key symbol' has a major role in inducing the imagination of this glorious past.

However, the historical origins of the flag are a subject of controversy. It is widely accepted among Arab nationalists that 'The Literary Club' (alMuntada al-'Arabi) that convened in Istanbul in 1909 and is considered by many as one of the first institutions of modern Arab nationalism, chose these four colors to symbolise the Arab nation (Abd el-Hadi 1986: 8). According to this version, the club's members were inspired by the words of the thirteenth century Arab poet Safi a-Din al-Hili: 'Our graces are white, our battles are black, our meadows are green and our swords are red.' While presenting its proposals, Filastin also mentioned this line of poetry to justify its choice of the four colors.

Another version dates the emergence of the Arab flag to the establishment of the Young Arab Society (al-Jamiyyat al-Arabiyya al-fatat) in Paris in 1911, an organisation founded by young Arab students that called for Arab independence. They chose green, black and white to represent the Arab nation. Each color, according to Arab mythology, served as a mono-color flag in a certain period of Arab historical independence: the Umayyad Empire (white), the Abbasid Empire (black) and the Fatimid Dynasty (green). In 1916, during the first year of the Arab revolt against the Ottoman Empire in the Hejaz, the forces of Hussayn hoisted a red flag that symbolised his Sharifian tribe. Only after a year of fighting did they adopt the tricolor blackwhite-green flag of 'al-Fatat' and added a red triangle (Qassimiya 1970: 12-14). 
A totally different version claims that the flag was designed by Sir Mark Sykes of the British Foreign Office and was offered by him to Faysal at the end of the war (Lias 1956: 109). When Allenby's army was preparing to advance from Jerusalem to Damascus, among its banners was also the quadra-color Arab flag, made by the British military supply offices in Egypt (Fromkin 1990: 109). Yet other versions attribute the 'copyright' of the flag to the Ottoman Administrative Decentralisation Party (the Cairo-based Hizb alLamarkaziyya), the British War office, field commanders of the Arab revolt and the Syrian general congress (Gelvin 1998: 244).

Whatever its origins, the Arab flag was widely disseminated. On 10 June 1917, on the first anniversary of the revolt, the pro-Sharifian Meccan newspaper al-Qibla published an official announcement on the raising of the Arab flag, including the flag description (Abd el-Hadi 1986: 10). Following Faysal's entrance into Damascus, the spread of rumors about the legendary victory of the Arab revolt was accompanied by a similar spread of images of the Arab flag and the use of its colors throughout Greater Syria

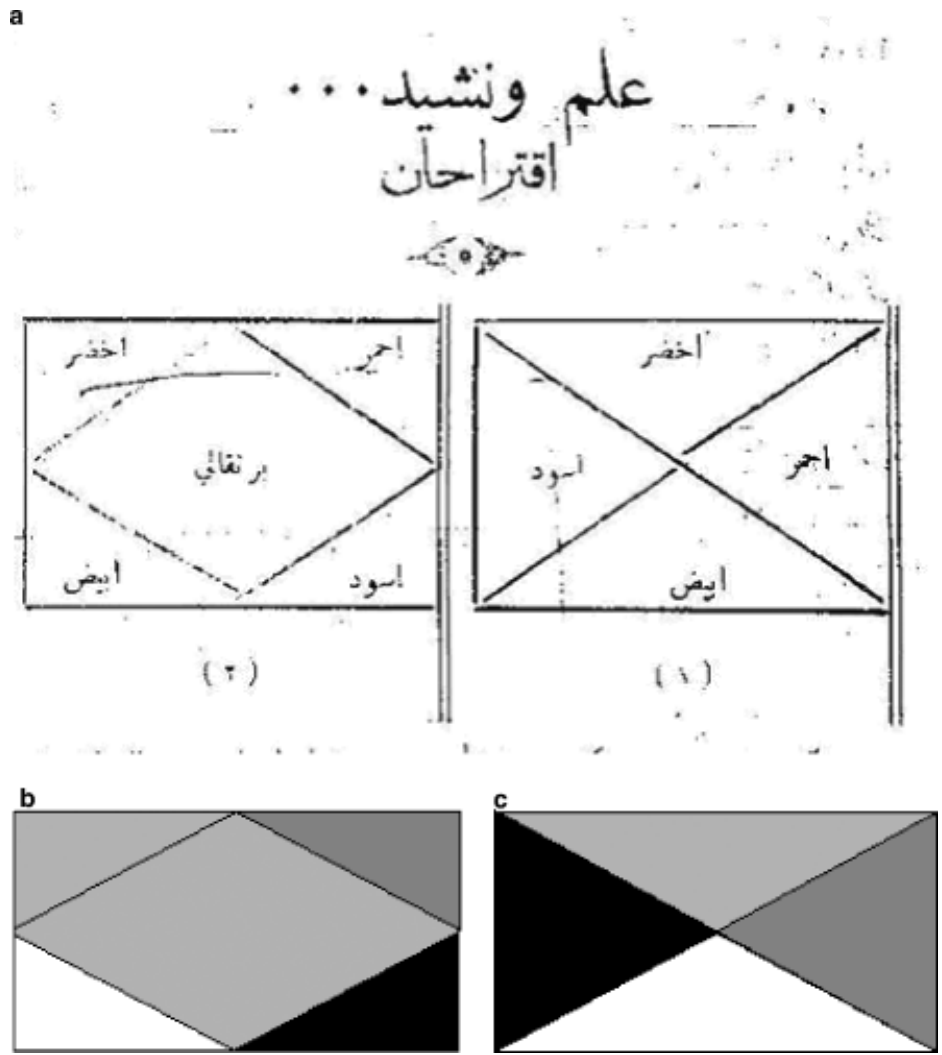

Figure 1. Original proposal in Filastin, 20 October 1929. Filastin's proposals, 20 October 1929 (rendered in colour by author according to verbal description) 


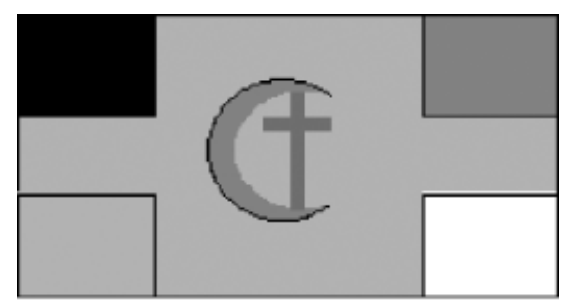

Figure 2. Assma Tubi's proposals, Filastin, 25 October 1929 (drawn by the author according to verbal description)

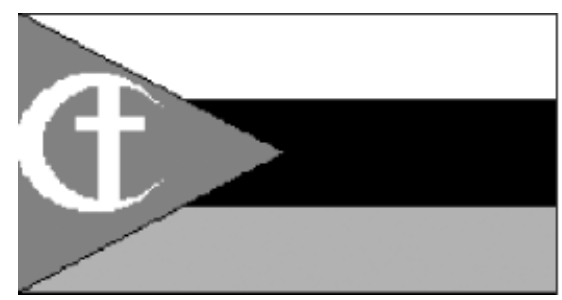

Figure 3. Husein Mikdadi's proposal, Filastin, 9 November 1929 (drawn by the author according to verbal description)

(Abd el-Hadi 1986: 12; Gelvin 1998: 244-5). In the conference of the MuslimChristian Association in Palestine that convened in Jerusalem on 5 March 1919, the Arab flag was hoisted alongside a banner with a crescent enclosing a cross - an emblem that was supposed to symbolise Muslim-Christian brotherhood (Abd el-Hadi 1986: 11).

Still, during the first years of the British occupation, Arab Palestinians were banned from hoisting the national Arab flag (while the Zionist flag was hoisted unhampered), under the pretext that it constituted the flag of a foreign state, the Hejazian state (Porath 1974; Abd el-Hadi 1986: 11). It is possible to assume that this prohibition intensified the tendency with which activists in the national clubs and the Scouts associations established during the Mandatory period considered the Arab flag as a symbol of Arab Palestine.

The pre-embeddedness of the four Arab colors in Filastin's readers' consciousness is obviously reflected in the fact that all of those who sent their comments and proposals adopted these colors. Even readers who were critical of these colors only proposed supplements and did not call to eliminate even one of them. For example, the author Asma Tubi from Acre complained: 'Concerning the flag, I do not understand its meaning and I do not think that foreigners will understand from it anything but that by its four colors it symbolizes hope and peace and later despair and blood ${ }^{7}$. Therefore, Tubi suggested adding the orange color and the 'Cross in the Crescent' emblem (Figure 2). 
Two weeks later the reader Hussni al-Mikdadi, agricultural engineer from Bethlehem, responded to Tubi's words that the colors symbolise blood and despair: 'The red color symbolizes war and inspires the nation to have the mental strength necessary to not give up its life and independence. The black color reminds us of our heroes who were killed and the sorrow of the people over them, ${ }^{8}$ Besides that, he claimed, Palestine has spiritual and political relations with the other Arab states that the flag symbolises. Mikdadi suggested that Palestinians adopt an Arab flag with a 'Cross in the Crescent' emblem in the red triangle (Figure 3).

Another reader who was also reluctant to emphasise Palestinian distinctiveness sent a letter to the $\mathrm{AE}$ and expressed explicit objection to the color orange appearing on the flag, since it might blur the flag's similarity to the flags of the neighboring Arab countries thus ignoring the facts that 'the Arabs have one interest, in every place and in every time'. This reader, who signed as 'an Arab from Haifa', enclosed with his letter ten examples of a possible Palestinian flag, all of them based on different combinations of the four colors of the Arab flag and the Cross in the Crescent emblem (Figure 4). ${ }^{9}$ Hamdi Can'an from Nablus also requested maintaining the symbolic similarity with the other Arab countries, and he proposed adopting the 'flag that was agreed upon at the convention in Damascus in Faysal's time: the Arab flag with three stars in the red triangle ${ }^{, 10}$ (Figure 5).

Among all the diverse proposals, one is exceptional in its political orientation. Elias Hana Rantissi from Jaffa argued that the proposals published in Filastin were artistically inappropriate and suggested his own design (Figure 7): three vertical strips - green, white and black, and a full red circle in the middle. Rantissi admitted that his flag was similar to the Japanese flag, but he did not see it as a deficiency since Japan was, in his words, 'a great Eastern nation' and 'the pride of the East'. ${ }^{11}$

To conclude, although the Palestinians who took part in the public discussion over the national flag differed in their level of aspiration of accentuating Palestinian singularity and their imagination of the future orientation of Palestine, they were unanimous in accepting that Palestine should express its belonging to the Arab world on its flag. The probable reasons for this consensus will be discussed later.

\section{The orange - Palestinian identity as 'natural'}

Whereas the proposal in Figure $1 \mathrm{~b}$ reflects Palestinians' identity as Arabs, the second proposal of Filastin (Figure 1c) strives to signify their distinctiveness as Palestinians. In this design the newspaper suggested adding a fifth color to the four Arab colors, the color orange, which was supposed to represent the orange fruit, one of Palestine's most important exports. Most of the readers' reactions reflect agreement with the supplemental color. One of the readers, 


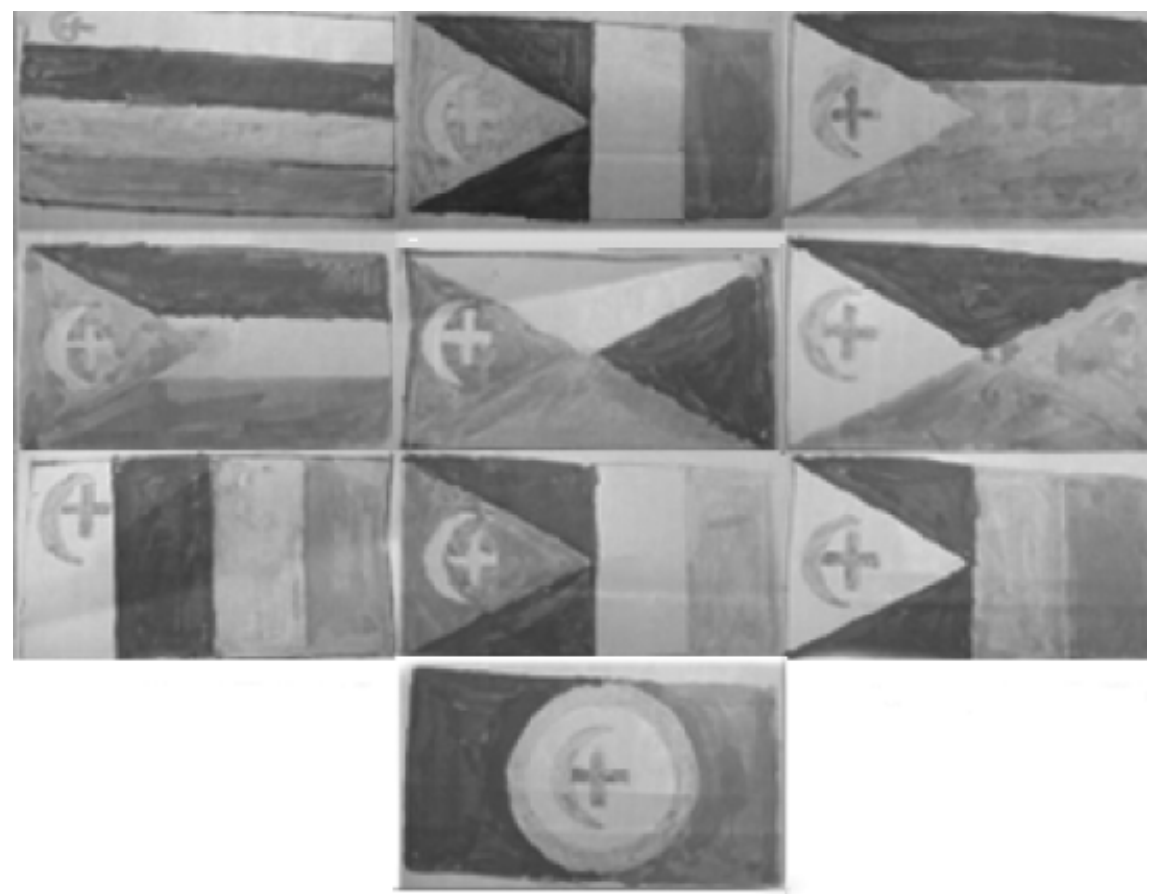

Figure 4. Proposals of 'An Arab from Haifa', Photos of original designs from: The Palestinian Flag, ISA (Israel State Archives), RG 65/box 985/file 49

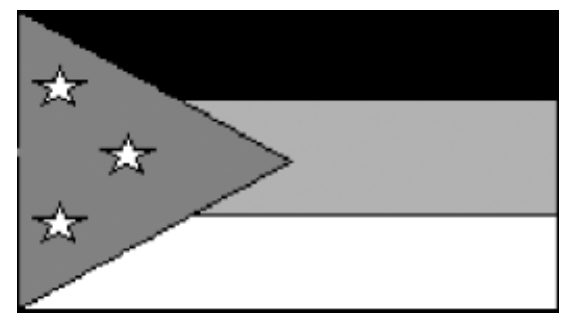

Figure 5. Proposal of Hamdi Can'an from Nablus, Filastin, 9 November 1929 (drawn by the author according to verbal description)

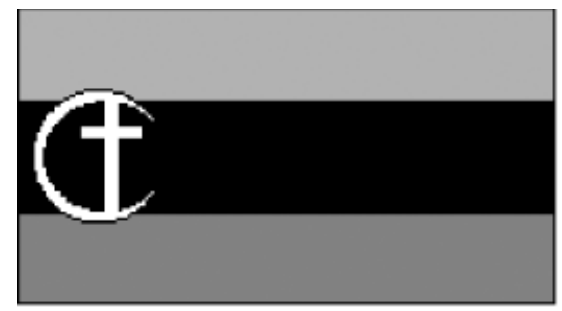

Figure 6. Proposal of 'Jalili' from Jerusalem, Filastin, 9 November 1929 (drawn by the author according to verbal description) 
Munir Dakak from Jerusalem, even proposed drawing an orange on the flag (Figure 8a). ${ }^{12}$

Where did the idea of representing the orange on the national flag stem from? This issue is related to the parallel development of both the orange orchards on the Palestinian coastal plain and the concept of nationalism in Palestine during the second half of the nineteenth century. From the middle of the nineteenth century, following the improvement of transportation methods and the stabilisation of political conditions, the Palestinian coastal plain underwent rapid urbanisation and economic change. This change was

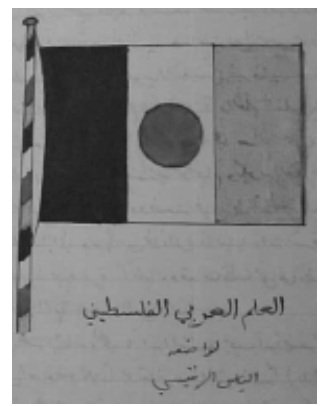

Figure 7. Elias Rantissi's proposal (photo of original designs from: The Palestinian Flag, ISA (Israel State Archives), RG 65/box 985/file 49
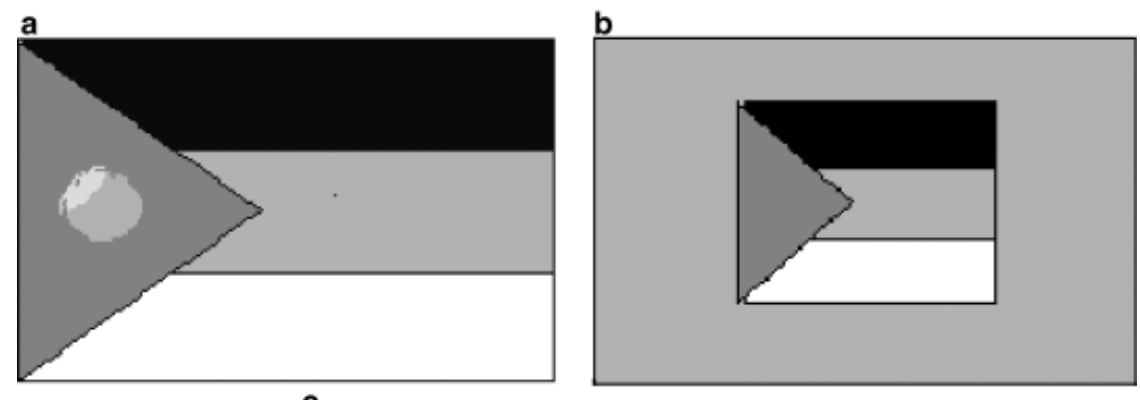

c

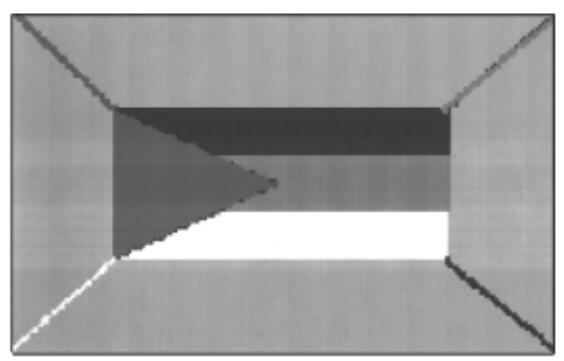

Figure 8. Proposals of Munir Dakak from Jerusalem in a letter to the AEC, dated 20 October 1929 - The Palestinian Flag, ISA (Israel State Archives), RG 65/box 985/file 49 (drawn by the author according to verbal description) 
accompanied by more intensive contacts with European agents such as merchants, pilgrims, missionaries, tourists and settlers (Kimmerling and Migdal 1993). A major by-product of this encounter was the import of Western ideas and ways of life, including the concept of the nation-state according to the nineteenth century European model (Shamir 1968). Before War World I, and especially after the Young Turk revolt in 1908, this influence was expressed mainly in demands for reforms in the multi-ethnic Ottoman Empire toward a more citizenship oriented regime (Campos 2003). With the collapse of the Ottoman Empire, the model of ethnic-organic nationalism, which demanded the overlapping of ethnic-cultural boundaries with political boundaries, became more popular.

Simultaneously, the Palestinian coastal areas witnessed an accelerated development of the orchard economy, following the discovery of the economic benefits of marketing the fruit overseas (Kimmerling and Migdal 1993). Palestine's orchards and their harvests became a major export branch: already by 1911, Jaffa's citrus industry was shipping 870,000 cases of oranges abroad, which accounted for almost one-third of the port's export income. ${ }^{13}$ The oranges were famous abroad and gradually grew to be part of the external image of the country. This external image eventually became a collective self-image.

Hence, when the Palestinian coastal elite in 1929 requested to choose a symbol that represented the idea of a Palestinian nation-state and emphasised Palestinian singularity, the idea of Palestine as the orange country was almost self-evident. It is very likely, however that this choice reflected to a large extent the world-view of the elite of the coast where the orange orchards grew and supplied the income of many families, and not a general Palestinian vision. Therefore, it is likely that among the inhabitants of the mountainous region of Palestine, this choice was less self-evident. The orange was not the only crop that was suggested for the flag. In one of the proposals sent by As'ad Shufani from Nazareth, he added two other examples of typical Palestinian crops more common in the Galilee, where he was from - an olive branch and a wheat spike ${ }^{14}$ (Figure 9).

The attempt to link a collective self-image with a crop is a sub-genre of a common phenomenon among modern nationalist movements - the extensive use of botanic and agricultural metaphors to describe the nation (Malkki 1992). Such a discourse presents the relations between national identity and territory as part of the natural order of the world. Nevertheless, a concrete representation of the local plants and wild animals of the country is not so common on national flags. It is not coincidental that most of the countries that have chosen this option are former colonies. The creation of political symbols was an important element in the construction of national consciousness in the course of anti-colonial struggles. ${ }^{15}$ In this context, the choice of a local plant or a typical crop contains elements of defiance against the alien by means of emphasising the direct and unmediated relations of the natives to their territory. For example, Haiti has a palm tree on its flag, Mexico has a cactus and Belize placed a mahogany tree on its flag. Among Arab and 


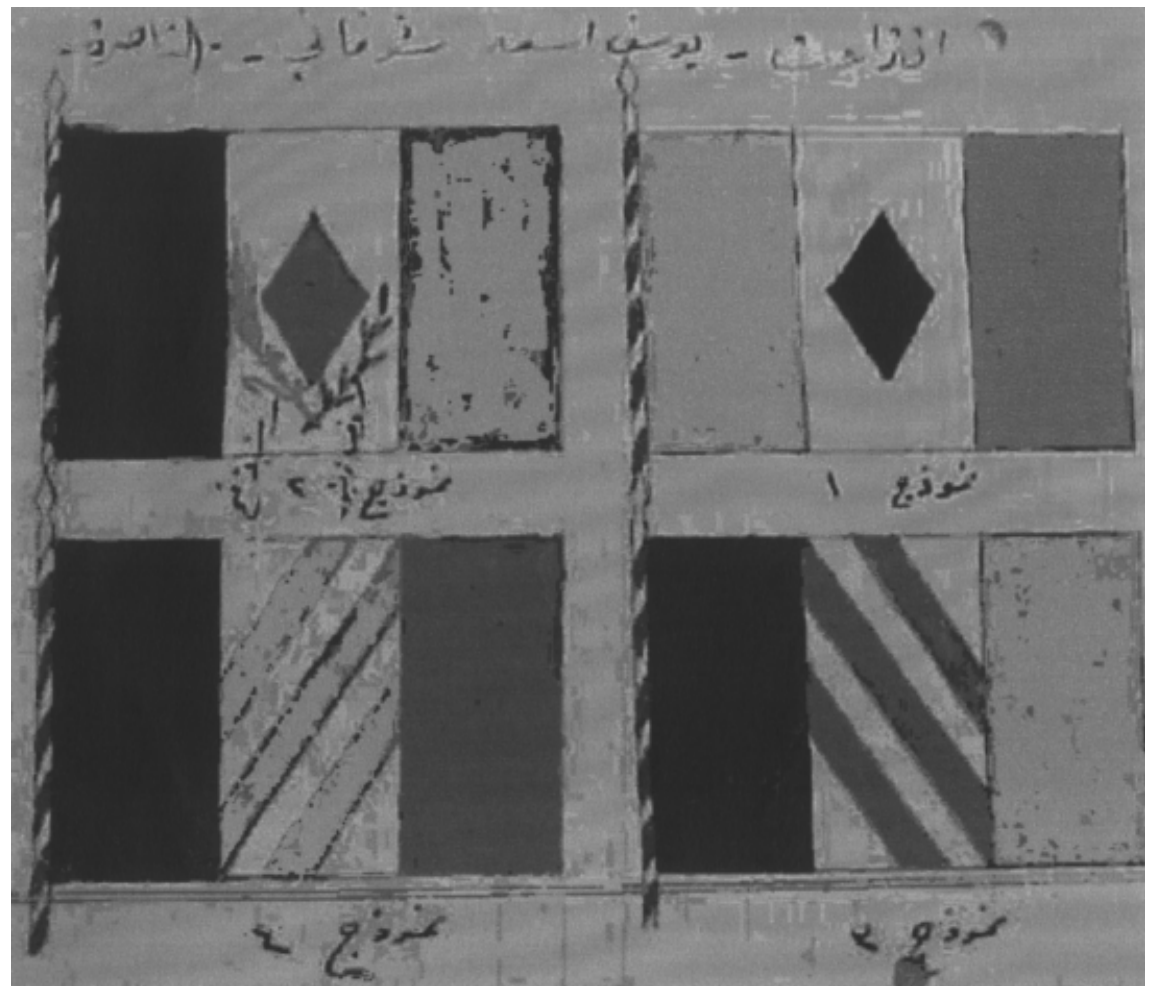

Figure 9. Proposals of As'ad Shufani from Nazareth, photo of original designs from: The Palestinian Flag, ISA (Israel State Archives). RG 65/box 985/file 49

Muslim countries only Lebanon chose to put a typical plant on its flag - the Lebanese cedar that served as a Maronite symbol during the Ottoman period (see the comparative discussion below).

The drive to emphasise nativity also stands behind the proposed representation of the orange on the Palestinian flag. The subtext of the color orange is: the Palestinian people, like the orange, grew naturally from the Palestinian terrain. The use of the orange as a collective representation enables Palestinians to present a 'natural' distinction from the neighboring Arab countries and a contrast to the 'artificial' Zionist movement that claimed sovereignty on Palestinian land even though it did not grow from it.

The choice of the orange signifies not only the existence of Palestine as a separate political unit, but also the qualitative difference between Palestinian identity and Arab identity in terms of the concept of territory. Although modern Arab nationalism was rooted in a geographic region loosely identified as the 'Arab world', the territorial component of this identity has always been marginal compared to the centrality of language and culture. In contrast, Palestinian identity by definition is a territorial identity. 
This fundamental distinction leads to another distinction regarding the level of exclusivity of the constructed boundaries of the two identities. The boundaries of Arab identity have not been open and inviting like the boundaries of Muslim identity, and like every national identity it has never aspired to include all humankind (Anderson 1991: 7). Nevertheless, the boundaries of Arab identity still maintained a certain level of diffusability and allowed a certain tolerance for the Arabisation of groups and peoples. This stands in contrast to territorial identities like Palestinian national identity, which are based on a much more rigid code of inclusion. ${ }^{16}$

Among Filastin's readership at the end of the 1920s, we witness the beginning of a process in which the sanctification of land and territory became a major element in Palestinian national identity - and that, even two decades before the forced exile of 1948. The mapping of Mandatory Palestine as a political unit with defined and rigid borders accelerated the growth of a distinct national consciousness, a process that serves as a classic example of Anderson's argument about the central importance of cartography for the ability to imagine the nation - even if this map was drawn by a hateful colonialist superpower (Anderson 1991: 170-7). Since Palestinian Arabs did not have a language distinct from their Arab neighbors, and because the regional cultural differences among Palestinians were no less than the differences between Palestinians and other Arabs from Greater Syria, the connection to territory became the central pillar of the crystallisation of Palestinian identity.

\section{The 'Cross in the Crescent' - Muslim-Christian brotherhood}

About half of the readers' proposals published in Filastin or sent to the AE included a certain combination of Muslim and Christian religious emblems, most frequently a crescent and a cross, that were supposed to symbolise the partnership and common fate of Muslims and Christians in Palestine. At first glance, this phenomenon is not surprising since the appearance of concrete religious symbols on national flags is a common phenomenon. A cross is featured on the flags of most European Protestant countries, remnant of the parallel development of territorial nationalism and the establishment of independent religious authorities separate from the Catholic Church. Likewise, a crescent appears on the flags of many Muslim countries from Tunisia to Malaysia, and the Israeli flag features a Star of David. Still, a national flag that combines emblems of two different religions constitutes an innovation ${ }^{17}$. Readers' proposals were inspired by the singular Palestinian experience in which an external threat (from the Zionist movement) produced an ad hoc pact between two communities who had shared many tensions in the past.

The birth of the Palestinian national movement is related to the essential rapprochement that occurred between Muslims and Christians in the country in the aftermath of the Balfour Declaration and its threatening implications 
for Palestinians. The Muslim-Christian associations that proliferated all over the country beginning in the fall of 1918 constituted the main organisational infrastructure of the Arab Palestinian national movement during the 1920s (Porath 1974). This movement adopted the 'Cross in the Crescent' emblem, similar to one used previously by the mixed Muslim-Christian brigades established at the end of the nineteenth century in the Ottoman army (Karpat 2001: 315). In the same way that Muslim-Christian rapprochement was partly motivated by the Zionist menace, it is plausible that those who decided to adopt the Cross in the Crescent were inspired by the centrality of a Jewish religious emblem, the Star of David, on the Zionist flag.

It is worth mentioning, though, that unlike many readers' proposals, the editorial proposals of Filastin did not include religious symbols at all, and the same is true for the words of the proposed anthem that appeared alongside the flags. Filastin suggested adopting the anthem of the Palestinian Scouts that did not mention the words 'Muslim' or 'Christian', but rather included only a general assertion that Palestinian brotherhood crossed religious affiliations: '...whatever the religious differences between us or differences in age, the brotherhood unites us with God's (help) - oh, homeland'. ${ }^{18}$

These are not merely semantic distinctions. There is an essential difference between the perception of Palestinian identity as an alliance between two religious communities, as reflected in the proposals that included a cross and a crescent, and the assertion of a homogeneous collective entity, indifferent to the religious affiliations of its members - an approach reflected in Filastin's editorial proposals. This distinction was well expressed later by Muhammad' Izzat Darawza, the founder and leader of the secularist Istiklal party, who in 1931 successfully proposed changing the official name of the MuslimChristian Association to the Arab National Association (Porath 1974: 277).

In contrast to the flags suggested by Filastin's editors, many of its readers chose to emphasise the fraternity of the two religious communities (Figures 2, 3, 4, 10 and 11). The very decision to accentuate these distinctive religious identities on the flag testifies to the extent that the category of religion was significant for those readers, and to their vision of the developing Palestinian identity as a 'welding' of two communities more than a 'melting' into one entity.

\section{Comparative discussion}

While viewing these spectacular and colorful flag proposals, one thing should be kept in mind - not a single one of them was adopted by the Palestinian political leadership, and it is unknown if they ever were discussed seriously by the AE. This might be due to circumstantial reasons: the inimical attitude of Filastin to the AE and to the Husayni family's leadership at that time, and the identification of 'Isa al-'Isa with the Nashashibi family in opposition (Porath 1974 and 1977). Still, this account fails to deal with the lack of popular enthusiasm beyond Filastin's audience for adopting the new symbols. In order 


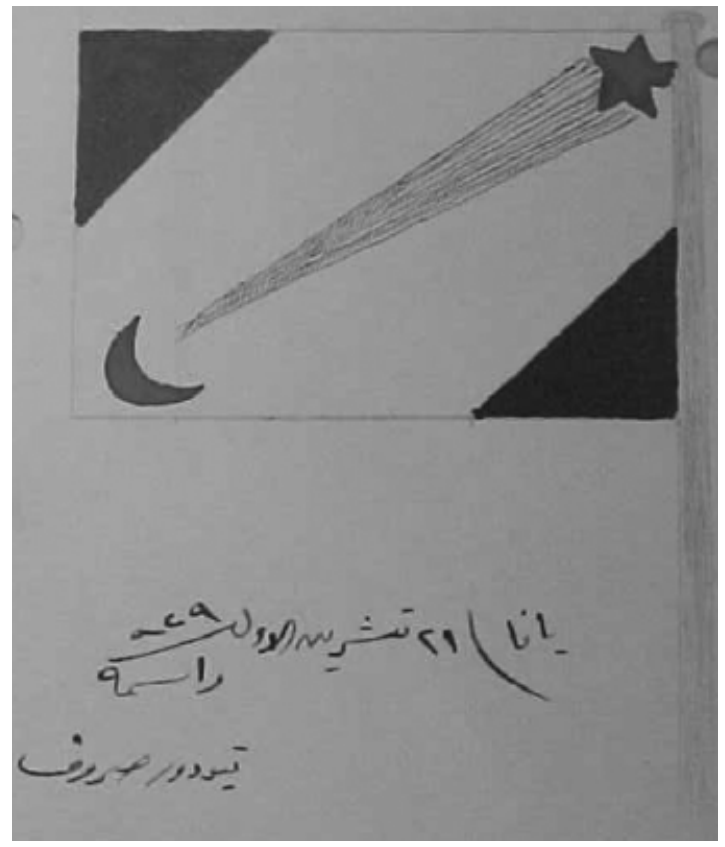

Figure 10. A proposal sent by Theodore Saruf, a Christian owner of a public relations office in Jaffa. Like all the other designs; his proposal included the colors of the Arab flag. His design intended to emphsise Muslim-Christain fraternity by the crescent projecting a ray of light with a five point star at its end (photo of original designs from: The Palestinian Flag, ISA (Israel State Archives), RG 65/box 985/file 49

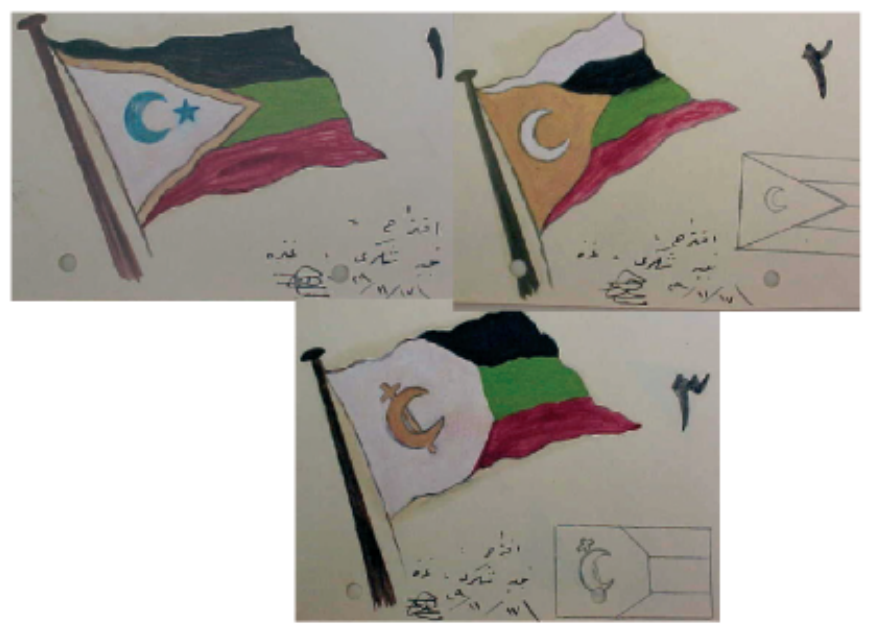

Figure 11. Proposals sent by Najih Shukri from Gaza (photos of original designs, dated 17 November 1929, from: The Palestinian Flag, ISA (Israel State Archives), RG $65 /$ box $985 /$ file 49 
to explain the failure of the campaign for a particular Palestinian flag, I will examine the cases of two other flags that eventually became official national flags - the 'Arab flag' (that eventually became the Palestinian flag) and the Lebanese national flag.

\section{The Arab flag}

The Arab rebellion (of the Sherifian tribe) against the Ottomans took place in the Hejaz and not in Palestine, and the Palestinians were not an integral part of this fight. In contrast, in the violent confrontations of August 1929, the Palestinians themselves were directly and exclusively involved and paid with their own victims. Nevertheless, the 'Arab flag' raised by the Hashemites was enthusiastically adopted by Arab Palestinians in 1918, whereas the proposals of Filastin following the 1929 riots did not arouse any such popular passion. The gap between the popularity of pan-Arab symbols and the proposed Palestinian symbols was expressed in the proposals of Filastin's readers. All these proposals, without exception, included the four Arab colors, but about half of them omitted at least one of the distinctive Palestinian emblems, the color orange or the 'Cross in the Crescent'. How can this difference be explained?

According to Anthony Smith's ethno-symbolism approach (Smith 1999), the ability of the intelligentsia to mobilise the masses to politicise their culture depends frequently on the pre-existence of a common ethnic set of myths and symbols. Based on the available sources, it is hard to assess to what extent the Arab flag's colors were rooted in an ancient common cultural-historical background. Even the historical references that attribute each of the four colors to a certain Muslim house or dynasty do not claim that the combination of the four colors was ever meaningful to Arabs or Muslims anywhere. Even the famous quote from Safi a-Din al-Hili's poem, because of its singularity, looks like a post-factum selective choice aimed at inventing a tradition.

Concerning the colors of the Arab flag, it is more likely that history provides rare windows of opportunity in which the consciousness of the masses is open and flexible to absorbing new key symbols. The socio-political circumstances in the Middle East after the end of World War I supplied such a moment, as Gelvin described it:

Although fictive boundaries of identity are ordinarily 'soft' - that is, relatively flexible, nonexclusive, and unselfconscious - they become reified during periods of mobilization and crisis, when individuals and the communities of which they are part directly confront their counterparts as 'the other'. As should be evident, the twenty-two months that followed the end of World War I, particularly the interval that extended from January through July 1920, constituted such a period. (Gelvin 1998: 146)

The collapse of the centuries-old political order with the dismantling of the Ottoman Empire created an anomic socio-political atmosphere in the Middle East. To borrow the terminology of the anthropologist Victor Turner, we 
would say that the inhabitants of the empire in general and the Palestinians in particular went into a 'liminal stage', when the old order disappeared and the new order was not yet crystallised. Under these cataclysmic conditions, public consciousness is like a metal coin at a very high temperature, and political symbols have better potential to be inscribed on it.

This symbolic imprint had long-term implications. Readers' reactions indicate that by the end of the 1920s, the colors identified with Arab nationalism already had gained a steady presence among the Palestinian elite. However, compared to the upheaval caused by the aftermath of World War I, the political crisis in Palestine in 1929 did not bring about the collapse of the British Empire, nor did it bring a change of rule in Palestine. Although the 'Thawrat al-Burak' had far-reaching implications in historical perspective, it did not change daily life and order, and hence did not provide an important precondition for the acceptance of new symbols.

At first glance, the 'Cross in the Crescent' emblem has a similar status to that of the 'Arab flag', since both were brought to the forefront of Palestinian political life during the interim period between the collapse of the Ottoman Empire and the establishment of a new political order. And indeed, while there is no evidence that a flag containing the color orange was ever raised, there is evidence that an Arab flag with the 'Cross in the Crescent' emblem was raised during the revolt against British rule in the 1930s. However, this emblem has not been carved into Palestinian collective memory like the Arab flag itself.

It is possible to speculate two main reasons for this difference. First, the demand to include a cross in the national flag coincided more with the Christians' aspirations, whose belonging to the emerging national community was less self-evident than the Muslims. Hence the fading of the 'Cross in the Crescent' from collective Palestinian symbolism stems from Christian demographic inferiority and the legacy of Islamic hegemony in the region.

As long as the idea of pan-Arabism remained mainly an intellectual project before War World I, the relative weight of Christian thinkers and scholars in formulating Arab national ideology was much higher than their demographic power. This phenomenon reflected their over-representation among the educated elite in the Middle East. However, after the demise of the Ottoman Empire and the popularisation of pan-Arab ideas, the Arab national movement was painted in deep Muslim Sunni colors and the Christian influence was diluted.

This tendency was noticeable in the popular accounts of the origins of the Arab flag's colors, which were attributed to the glorious days of Islam. Furthermore, the Muslim masses in Greater Syria embraced Arab nationalism wholeheartedly and it became for them synonymous with Islam (Zamir 1997). These feelings were motivated partly by the hope that their nationalist commitment would assist them in ensuring their religion and culture and their dominance in the Syrian Arab state. The Hashemite dynasty, which used its alleged genealogic relationship to the prophet as a source of legitimacy for its 
authority and its control over the Fertile Crescent, emphasised Muslim-Sunni dominance.

In Palestine, although the eruption of violence in 1929 all over the country stemmed mainly from the growing anxiety of the Arab population over being dispossessed by the Zionists, the political leadership headed by Hajj Amin alHusayni intensively merged Muslim symbolism into this anxiety. The Christian identity of the British rulers also did not help to solidify the supra-religious character of the uprising. Christian intellectuals fought back against their own marginalisation by pushing forward their symbols: For example, Palestinians who were executed by the British for their participation in the murderous riots of 1929 were compared in Filastin to crucified Jesus. ${ }^{19}$ The attempt to promote the 'Cross in the Crescent' to center stage was just another expression of this tendency. Their success, however, was quite limited. The political body that symbolised Muslim-Christian partnership and promoted the 'Cross in the Crescent', the Muslim-Christian Association, suffered from acute fluctuations of its power and its level of activity until it ceased to play a significant role in Palestinian politics by the mid-1930s (Porath 1974).

Second, like the orange, the local connotation of the 'Cross in the Crescent' prevented it from acquiring the same status as the four-color flag, which at the end of the 1920s was already identified with the entire Arab nation. In the eyes of many Palestinians, perhaps, belonging to a greater entity could have potential political dividends in their struggle against Zionism.

\section{The Lebanese flag}

While discussing the symbolic emphasis of territorial distinctiveness it is necessary to compare Palestine with Lebanon, the only Arab country whose flag contains an emblem with unambiguous territorial significance. The Maronites of Mount Lebanon, who achieved limited autonomy in the mid19th century, chose the cedar as their symbol. Later, in 1943, their hegemony in the broader Lebanese state allowed them to place the cedar at the center of the Lebanese national flag. The notable place of Christians in both national movements - hegemony in Lebanon and prominence in Palestine - plays an important role in explaining why in both countries a significant part of the population was not satisfied with another version of the Arab flag and many demanded giving expression to the territorial distinctiveness of their country.

As mentioned earlier, although Muslim symbolism was dominant in panArab ideology even before War World I, it became even more salient following the demise of the Ottoman Empire. Therefore, in spite of the status of prominent Christians among the theoretical formulators of Arab nationalism, which they saw as a solution to their marginality in the Muslim world, among Christians in the Middle East (like other religious minorities) some concerns were raised that Arab nationalism would perpetuate Sunni dominance (Rabinovich 1977). Therefore, during the first decades after World 
War I many Christian leaders in Arab countries were active in political and cultural movements that demanded accentuating the territorial distinctiveness of their countries, sometimes even frankly rejecting pan-Arabism.

During the 1920s and 1930s for example, the Copts in Egypt played a prominent role in the 'resuscitation' of the Pharonic legacy of Egypt (Reid 1997). During the exact same period, the Phoenician movement in Lebanon gained popularity among Maronites in Lebanon (Kaufman 2001). Likewise, Anton Sa'ada's Syrian National Socialist Party, which was established in 1930 and promoted the ideology of a distinctive Syrian identity, had an overrepresentation of Greek-Orthodox Christians from Syria and Lebanon in its ranks. To a certain extent, the demand to place both the cedar and the orange on the national flag is rooted in the anxieties of Arab Christians about their status as a minority in the Middle East as well as their suspicious approach toward pan-Arab nationalism.

In spite of the similarities between the cedar and the orange, this pair of national symbols had different fates. Whereas the first was placed in the center of the Lebanese national flag, the latter has never appeared on an official Palestinian symbol. Several factors might explain this difference.

First, and most important, the social status of the groups who asked to emphasise the particular territorial distinction was not identical in the two countries. In Lebanon, Maronite hegemony at the time of independence enabled them to force their desires on the Muslim communities in Lebanon. The lack of popularity of the cedar flag among the Shiite community is well expressed these days: in the Shiite villages in the south of Lebanon (evacuated by the Israeli army and controlled today by the Shiite militia Hizballah), the most widely seen flag is the yellow Hizballah flag and not the Lebanese national flag. As opposed to the Lebanese cedar, the Palestinian orange lacked a powerful and firm lobby and its 'base of power' was mainly the tiny Christian intellectual elite that had little access to the centers of political power, and the orchard owners as representatives of a specific class.

Second, the cedar has a biblical reference with an explicit connection to Lebanon, which bestows it with popular recognition and cultural-historical depth. The orange, on the other hand, is not mentioned in the Holy Scriptures, ${ }^{20}$ and therefore it is more difficult to connect it with an ancient Palestinian past. Nevertheless, a biblical reference is not a prerequisite for a plant to appear on a national flag, as we know from the maple leaf on the Canadian flag or the cactus on the Mexican flag.

The cedar emblem has another important advantage: timing. The cedar flag was raised by Maronites in Mount Lebanon a few decades before the birth of the Arab flag, since Lebanese territorial identity began to crystallise long before Arab nationalism and even received political expression with the establishment of the autonomous district of Mount Lebanon under the Ottoman Empire in 1861. In contrast, the attempt to raise an orange flag encountered a political reality in which Arab nationalism was already deepseated among both the elites and the masses in Palestine. 
Fourth, Lebanon differed from Palestine in the sense that the Zionist threat was not hanging over its residents' heads. It might be that Palestinians felt unconfident to differ too much from the rest of the Arab nation, especially when the country's future was uncertain. That is, the Zionist threat, which formed on the one hand a catalyst for the consolidation of a separate consciousness, served on the other hand as a brake against a complete disconnection.

\section{Conclusion and epilogue}

The disappearance of the orange and the 'Cross in the Crescent' from Palestinian collective memory implies that not every symbol suggested by the elite will be adopted by the masses. Some prerequisites are needed for symbols to gain a stable presence in national consciousness. The Arab flag broke into the public arena under cataclysmic circumstances in terms of the socio-political order, and it was associated with a potential political back up for the Palestinians in the form of the Arab nation. The 'Cross in the Crescent' had only the first attribute whereas the color orange lacked both. The Lebanese cedar gained institutional recognition because of a combination of several factors: successful timing concerning the power relations between different elites, the biblical reference of the cedar that helped to connect it to an ancient past, the fact that it historically preceded Arab nationalism, and the fact that the Lebanese were not threatened by an external power and felt more confident to distance themselves from pan-Arabism.

In the years after 1929, the Palestinian national movement continued to use the 'Arab flag' as their flag, even though during the Mandatory period there was some confusion with regard to the correct order of the horizontal stripes, and it was possible to find different versions (Qassimiya 1970). In spite of the official ban by the British authorities, the Arab flag was raised in official events that were designed to emphasise national identity, such as sports competitions organised by the independent Arab sports association (Sorek 2003). In March 1948, following the evacuation of the British forces from Gaza, the 'All Palestine Government', presided over by Ahmad Hilmi Pasha, declared the establishment of a Palestinian state and chose the Arab flag as its formal national flag. This flag was raised in Gaza until the arrival of the Egyptian army in the area two months later. In 1952, following the Free Officers' coup in Egypt, the Arab flag was re-raised on public buildings alongside the Egyptian flag. In 1955, Ya'qub Khuri, the director of the Palestine department in the Arab League, suggested adding another flag to represent Palestine - the word Palestine in red on a white background, which would symbolise the bloody state of Palestine. This flag was raised indeed in the Palestinian offices in the Arab League until it was removed due to the protest of the Prime Minister of the 'All Palestine Government' (Qassimiya 1970: 29-33). 
The 'Cross in the Crescent' and the color orange never have been recognised as official Palestinian emblems nor were they ever officially suggested as features for the Palestinian national flag. The sharp decline of Christians' weight in the Palestinian national movement after 1948 and the two waves of accelerated Islamisation of Palestinian identity (in the 1930s and from the mid-1980s) (Litvak 1996) have diluted the concept of Palestinian nationalism as a Muslim-Christian alliance. The orange orchards and fruits are indeed well represented in the 'nostalgia literature' of the Palestinian refugees, where they symbolise the tragic Palestinian destiny and the natural connection of an uprooted people to its land (Bardenstein 1998). However, the color orange in and of itself rarely constitutes a part of the contemporary national symbolic set of Palestinians.

Still, in one of those strange ironies of history, two things happened. First, during the first decades after the establishment of the state of Israel, the orange fruit was adopted by Israelis as an Israeli national symbol, as Jewish agriculturalists had also been harvesting citrus. At the same time, after Israel occupied the West Bank and Gaza Strip in 1967, the military authorities equipped the Palestinian inhabitants of these territories with orange identity cards. These were supposed to distinguish them from Israeli citizens, who hold blue identity cards. Today, in spite of the establishment of the Palestinian National Authority, the orange certificates are still valid. In a certain way, although imposed and unwelcome, orange is still a Palestinian color.

\section{Notes}

1 The catalyst of the revolt was a dispute over prayer rights at the holiest site for Jews, the Wailing or Western Wall, which is the only remnant of the Second Temple. The site is known to Muslims as 'al-Burak' after the name of the prophet Muhammad's horse, who according to Muslim belief was tied to the wall before the prophet ascended to heaven.

2 The Arab Executive formed the political leadership of Arab Palestinians during the 1920s. It was elected by the Muslim-Christian Associations from all over the country (see Porath, 1974).

3 Filastin, 19 October 1929, p. 3. While the publication of fictional letters from readers was not an uncommon phenomenon at the time, given Palestine's small size as well as the character of social life and the role of the extended family, it is highly unlikely that Filastin's editors would have dared to invent proposals from such highly specific and in most cases well-known families.

4 The public debate dealt with both the flag and the anthem suggestions. This article focuses on the flag debate, which was much richer and included more participants.

5 The revolt of the Sherifian tribes started in the Arabian Peninsula at the end of World War I and signified the end of Ottoman rule over Arab countries.

6 Unless otherwise specified all the color illustrations are my reconstructions of the flags imagined by the authors, according to their verbal instructions.

7 Filastin, 25 October 1929.

8 Filastin, 9 November 1929.

9 The Palestinian Flag, Israel State Archive, 65/P985/49.

10 Filastin, 9 November 1929.

11 The Palestinian Flag, Israel State Archive, 65/P985/49. It is important to note that since its victory against Russia in 1905, Japan has been considered in the Middle East as an example of a successful anti-colonialist power. 
12 A letter to the AEC, dated 20 October 1929 - 'The Palestinian Flag', Israel State Archive, 65/ P985/49.

13 Over $\$ 1,000,000$ out of $\$ 3.4$ million total. From: Commerce and Industries - Jerusalem Consular District, Calendar Year of 1911; 1 March 1912; Box 350 (Jerusalem); Records of the Foreign Service Posts of the Department of State, Record Group 84; National Archives, College Park.

14 The Palestinian Flag, Israel State Archive, 65/P985/49.

15 Plants and animals are relatively common on sub-nations' flags, such as the state flags in the US where they also serve to emphasise a distinctive local identity.

16 The Palestinian National Covenant, adopted in 1964, expressed this relation between territorialism and a rigid code of inclusion by stating that 'The Palestinian identity is a genuine, essential, and inherent characteristic; it is transmitted from parents to children...'. For a thorough analysis of different codes of inclusion and exclusion see Eisenstadt and Giesen 1994.

17 The closest case is the Irish flag in which the green and the orange represent the Catholic and the Protestant communities. However, the identification of these colors with Catholicism and Protestantism is highly related to the specific context and it lacks the world-wide recognition of the Cross and the Crescent.

18 Filastin, 20 October 1929.

19 Filastin, 18 June 1930.

20 Although a citrus fruit is mentioned in the Old Testament, the relevant verses have gained importance only in the Jewish tradition and not among Muslims or Christians. In addition, the traditional Jewish interpretation of the citrus mentioned in the Bible is the etrog citron and not the orange.

\section{References}

\section{Archival}

The Palestinian Flag, 65/p985/49, Israeli State Archive (ISA)

1 March 1912, Commerce and Industries-Jerusalem Consular District, Calender Year of 1911; Correspondence (January-July 1912); General Correspondence, 1912-35; Jerusalem Consulate (350/26/11/1-2); Records of the Foreign Services Posts of the Department of State, Record Group 84; NACP.

\section{Newspaper}

Filastin (newspaper), Jaffa, 1911-1947.

\section{Published sources}

Abd el-Hadi, Mahdi. 1986. Tatawur al-Alam al-Arabi min al-Fath al-Islami hata al Kurn al-'Ishrun. Amman, publisher unknown.

Anderson, Benedict. 1991. Imagined Communities: Reflections on the Origin and Spread of Nationalism. NewYork: Verso.

Bardenstein, Carol. 1998. 'Threads of memory and discourses of rootedness: of trees, oranges and prickly-pear cactus in Israel/Palestine', Edebiyat 8: 1-36.

Bellah, Robert. 1967. 'Civil Religion in America', Daedalus 96: 1-21. 
Campos, Michelle. 2003. A 'Shared Homeland' and its Boundaries: Empire, Citizenship and the Origins of Sectarianism in Late Ottoman Palestine, 1908-1913. Ph.D. Dissertation, Department of History, Stanford University.

Durkheim, Emile. 1969 [1915]. The Elementary Forms of the Religious Life. New York: Free Press.

Eisenstadt, Shmuel Noah and Bernhard Giesen. 1994. 'The construction of collective identity', Archives Europen de Sociologie 36: 72-102.

Fromkin, David. 1990. A Peace to End All Peace: The Fall of the Ottoman Empire and the Creation of the Modern Middle East. New York: Avon.

Gelvin, James L. 1998. Divided Loyalties: Nationalism and Mass Politics in Syria at the Close of Empire. Berkeley, Los Angeles and London: University of California Press.

Gerber, Haim. 1998. " "Palestine" and other territorial concepts in the 17th century', International Journal of Middle East Studies 30(4): 563-72.

Kabha, Mustafa. 1996. The Role of the Press and its Discourse in the Arab-Palestinian National Struggle. Tel-Aviv: Tel-Aviv University (in Hebrew).

Karpat, Kemal H. 2001. The Politicization of Islam: Reconstructing Identity, State, Faith, and Community in the Late Ottoman State. Oxford and New York: Oxford University Press.

Kaufman, Asher. 2001. 'Phoenicianism: the formation of an identity in Lebanon in 1920', Middle Eastern Studies 37(1): 173.

Khalidi, Rashid. 1997a. 'The formation of palestinian identity: the critical years, 1917-1923' in J. Jankowski (ed.) Rethinking Nationalism in the Arab Middle East. New York: Columbia University Press, 171-90.

Khalidi, Rashid. 1997b. Palestinian Identity: the Construction of Modern National Consciousness. New York: Columbia University Press.

Kimmerling, Baruch and Joel Migdal. 1993. Palestinians: the Making of a People. New York: The Free Press.

Lias, Godfrey. 1956. Glubb's Legion. London: Evans Brothers.

Litvak, Meir. 1996. The Islamization of Palestinian Identity: the Case of Hamas. Tel-Aviv: Moshe Dayan Center.

Malkki, Liisa. 1992. 'National geographic: the rooting of peoples and the territorialization of national identity among scholars and refugees', Cultural Anthropology 7(1): 24-44.

Porath, Yehoshua. 1974. The Emergence of the Palestinian-Arab National Movement, 1918-1929. London: Frank Cass.

Porath, Yehoshua. 1977. The Palestine Arab National Movement: From Riots to Rebellion. London: Frank Cass.

Qassimiya, Khayriya. 1970. Al-'Alam al-Falastini. Beirut: PLO Research Center, (in Arabic).

Rabinovich, Itamar. 1977. Religion and Nationalism in the Middle East: the Case of Lebanon. TelAviv: Shiloah Center for Middle Eastern and African Studies, Tel-Aviv University.

Reid, Donald M. 1997. 'Nationalizing the Pharaonic past: Egypt 1922-1952' in J. Jankowski (ed.), Rethinking Nationalism in Arab Middle East. New York: Columbia University Press, 127-49.

Shamir, Shimon. 1968. 'The impact of Western ideas on traditional society in Ottoman Palestine' in: M. Maoz (ed.), Ottoman Reform in Syria and Palestine, 1840-1861: the Impact of the Tanzimat on Politics and Society. Oxford: Clarendon Press, 507-16.

Smith, Anthony D. 1986. The Ethnic Origins of Nations. Oxford and New York: Basil Blackwell. Smith, Anthony D. 1999. Myth and Memories of the Nation. New York: Oxford University Press.

Sorek, Tamir. 2003. 'Palestinian nationalism has left the field: a shortened history of Arab soccer in Israel', International Journal of Middle East Studies 35(3): 417-37.

Weitman, Sasha. 1973. 'National flags: a sociological overview', Semiotica 8(4): 328-67.

Zamir, Meir. 1997. Lebanon's Quest: The Road to Statehood. London and New York: I.B. Tauris. 